\title{
Home is Calling: Hungarian Emigrants' Response to the Home Country's Return Campaign
}

\author{
Judit Molnár \\ Department of Cultural and Social Anthropology, University of Vienna \\ judit.molnar.2017@mumail.ie
}

Received: $14 / 09 / 16$

Accepted: $13 / 10 / 16$

Published: 30/11/2016

\section{Resumen:}

En el presente trabajo, ofrezco una visión general de los antecedentes que contribuyeron a las decisiones tomadas en la construcción de mi proyecto de investigación, que se centra en la motivación de los emigrantes húngaros que viven en Irlanda para repatriarse en la medida que se ven afectados por la campaña de retorno del gobierno húngaro. Después de un breve resumen de la literatura sobre la construcción de la diáspora y el transnacionalismo dirigido por el Estado, en el que se incorporará el estudio, así como la presentación de la matriz integración transnacionalismo que servirá de marco analítico, presento un estudio similar para resaltar los puntos que son relevantes para mi proyecto. A esto le sigue la descripción del contexto específico en el que se realiza la campaña de retorno húngaro y la presentación de los resultados de mi investigación preliminar: a través de esto, analizo ciertas tendencias que deben ser consideradas al analizar el grupo en el marco de mi investigación. Finalmente, abogo por las elecciones que hice basándome en estas premisas al presentar el plan de investigación.

Palabras clave: diáspora; identidad migrante; motivación para el retorno; transnacionalismo dirigido por el estado; construcción de la identidad nacional.

\begin{abstract}
In the present paper, I provide an overview of the background material that contributed to the decisions made in the construction of my research project, which focuses on the motivation of Hungarian emigrants living in Ireland to repatriate as affected by the Hungarian government's return campaign. After a short summary of the literature on diaspora construction and state-led transnationalism, in which the study is to be embedded, as well as the presentation of the integration-transnationalism matrix that is to serve as the analytical framework, I introduce a similar study to highlight the points that are relevant to my project. This is followed by the description of the specific context in which the Hungarian return campaign takes place and the presentation of the results of my preliminary research: through this, I discuss certain tendencies that must be considered when analysing the group in the focus of my research. Finally, I argue for the choices I made based on these premises as I present the research plan.
\end{abstract}

Keywords: diaspora; migrant identity; return motivation; state-led transnationalism; national identity construction. 


\section{Index}
1. Introduction
2. Overview of relevant literature
4. Preliminary research
5. Proposed research
3. The Hungarian context
6. Conclusion
7. References

\section{Introduction}

Since the start of the financial crisis in 2008, a growing number of people have left Hungary in search of a better future outside the borders. As the emigration of primarily young and educated people is leaving a strong mark on the economy, the government of the country has devised a campaign to attract its citizens back. The campaign that relies on the organisation of the diaspora communities and the fostering of patriotic feelings through various events and activities sets as its primary goal the reversal of emigrants' assimilation processes and the strengthening of transnational ties with the motherland. However, while existing literature does underline the role of the home state in the construction of diaspora identities and thereby, in the control over the emigrated community's future, research conducted to assess the results of a similar campaign highlights the limited functionality of such interventions. In this essay, I would like to present my research project that sets out to analyse the patterns in Hungarian emigrants' willingness to return and assess how such motivations result from emigrants' perceived integration - or lack of it - into the host culture and a new identity defined by transnational ties established with the home country, which are the two pillars the Hungarian government's campaign is built on.

In the present work, I will focus on the presentation of the background material that I relied on in the construction of my research and explain the choices I made based on these sources. After a brief summary of how the study fits into already existing theories on migration, I will introduce the framework of analysis which I intend to use to evaluate the data collected. This is to be followed by the description of a similar project that was carried out in the context of Ecuadorian emigrants living in Italy and a summary of its findings that can be relevant to my research. After this, I will give a more in-depth analysis of the Hungarian situation and share the results of a preliminary study that I carried out in March 2016 in order to assess certain tendencies amongst Hungarian migrants living in Ireland. In the last part of this essay, I will provide an overview of my research plan and argue for some choices made regarding its implementation.

\section{Overview of relevant literature}

While diasporas have traditionally been defined as historical victim groups that became dispersed through expulsion (Gamlen, 2008), this definition has been debated extensively in academic discourse since the 1960s, with increased attention paid to their importance in understanding certain migratory patterns and more recently, it has been applied to describe any group that lives outside its original homeland. The present consensus on what makes a group a 
diaspora includes the group's dispersal to multiple locations; the existence of permanent ties with the motherland and the long-term upholding of the group's boundary (Butler 2001; Brubaker, 2005). Such tendencies in academia have resulted in the inclusion of non-traditional emigrant groups in the narrative on globalisation and transnationalism and this accounts for why communities emerging through the recent migration of first-generation emigrants are often analysed as constituting a diaspora community. Moreover, as Weiner (1986) points out, besides banishment, diasporas are now understood as evolving stimulated by many other conditions, such as the search for better financial circumstances.

As Gamlen (2008) points out, the contested nature of diasporas stems from the essentialist (e.g. Conner, 1972) vs constructivist (Anderson, 1983) debate, in which clashing views on whether diasporas are pre-political, natural entities or the results of social constructions are at the base of the different treatment of their collective identities and whether researchers approach them as historically rooted and steady or as the result of the constant negotiations taking place as the result of socialisation. In recent scholarship, there has been increased attention dedicated to the role of the state in shaping diaspora identities (e.g. van Evera, 1994) and based on Anderson's theory of imagined communities, diasporas have been analysed as social and political constructions that are created and propelled through political discourse enabled by global communication.

In this process, it is important to examine the role of the home country and discuss state-led transnationalism, which is defined by Goldring (2002) as the "institutionalized national policies and programs that attempt to expand the scope of a national state's political, economic, social, and moral regulation to include emigrants and their descendants outside the national territory" (p. 64). Although, as pointed out by Levitt (2001), the forms, reasons and the extent of such involvement vary, the motivation in enacting state-led transnationalism normally stems from the perception of economic and political gain rooted in the diasporas (Portes, 1999). It is normally implemented through a political discourse that emphasizes nationhood ties and the identification of people living outside the border as part of the nation (Margheritis, 2007). This, according to Gamlen (2008), empowers emigrants through the creation of transnational collective identities that elevates them from forming part of a minority to being a member in a global network.

However, the increased attention devoted to the analysis of the political processes often tends to overshadow the individual's agency in the process. As Margheritis (2007) points out, apart from a few notable studies (e.g. Guarnizo et al., 2003; Itzigsohn, 2000; Levitt and de la Dehesa, 2003; Østergaard-Nielsen, 2003), the impact of the motherland's intervention on the members of the diaspora has been devoted little attention in scientific analysis. This gap was aimed to be filled by Boccagni (2011), who set out to analyse the way a diaspora community in Italy was affected by the initiative of Rafael Correa, who, after becoming the president of Ecuador in 2007, implemented the programme Bienvenid@ A Casa: Por un regreso voluntario, digno y sostenible (Welcome Home: for a voluntary, dignified and sustainable return). The aim of the initiative was to encourage members of the diaspora to repatriate, which was hoped to be achieved through the strengthening of feelings of belonging 
and national identity by an online campaign and the offering of substantial funds that would assist people's transition. As Boccagni highlights - similarly to the Hungarian case - the two pillars of programme were the cultural and the economic return: the cultivation of transnational ties between the migrant and the motherland and the stimulation of conditions in the home country for the migrants that make life in Ecuador more attractive than their current one outside the borders.

In his study, Boccagni relied on interviews with the members of the Ecuadorian diaspora in Northern Italy to assess how the campaign influenced migrants' motivation to return. While his study underlined that the campaign strengthened national identity, with feelings of loyalty and obligations towards the home country, as well as ties to the family and social networks, coming to the forefront, this was not enough to counterbalance the fact that emigrants were aware that the conditions that were needed to sustain a satisfying life in their home country were missing. Moreover, the research highlighted that the willingness to return is an unreliable predictor of actual repatriations and that although almost without exception, all of his interviewees planned to return at a certain stage, very few of them actually did so. While Boccagni concluded that "aiming to strengthen migrants' homeward ties 'from above' may sound naive and ideologically charged" (p. 468) and that Ecuador did not gain significant human capital in the process, he also identified several ways the home country benefited from the enhancement of the relationship between itself and its diasporas.

As King (1999) emphasizes, most return migration takes place spontaneously, little affected by the mother state's policies, but instead motivated by the individuals' independent assessment of the push and pull factors involved, like their feelings of belonging and well-being in the two countries. However, in the Hungarian case, it is exactly people's perception of the push and pull factors that the campaign aims to alter. Therefore, in order to understand the processes that lie at the core of the individual's return intentions, I propose the use of Carling and Pettersen's (2014) framework, the 'integration-transnationalism matrix'. The model relies on the assumption that integration and transnationalism are converging dimensions and each can be evaluated on a scale between weak and strong. Carling and Pettersen show that based on the assessment of the relative strength of these independent factors, a matrix of four possible outcomes might be drawn up: people feeling strongly transnational and weakly integrated are the group most likely to return while those who are feeling weakly transnational and strongly integrated the least likely. As the campaign in the focus of my research operates aiming to strengthen people's understanding of themselves as being connected to the motherland and weaken their feelings of being integrated in the host country, the evaluation of people's perception of the relative strength of these components in their lives and their change over time can be used to assess the success of the campaign.

\section{The Hungarian context}

As Bodnár and Szabó (2014) highlight, although Hungary's joining of the European Union in 2004 created the necessary preconditions for the large scale movement of people, it did not start the process of mass emigration like it did in 
many other Eastern European countries. What changed this tendency, however, was a the financial crisis starting in 2008, as a consequence of which around 800.000 people have left the country, the majority of whom were motivated directly by the deterioration of the economic situation in Hungary. During the past half a decade, the popularity of emigration as a coping strategy has augmented dramatically and since 2012, the number of those leaving the country with the aim of starting a new life outside the borders has increased sixfold.

According to the study of Bodnár and Szabó, of those people who emigrated during the past decade, $80 \%$ are under 40 years old and $32 \%$ of them possess a higher education certificate, which is in clear contrast with the $19 \%$ who have benefitted from education beyond a secondary school certificate in the country. Moreover, those who never studied beyond primary school make up $24 \%$ of the population remaining at home, but only $9 \%$ of the emigrants. This means that the country is not only losing citizens constituting the most important labour force, but that a significant tendency of 'brain drain' is observable as well. Moreover, according to the Hungarian Központi Statisztikai Hivatal's (Central Statistics Office) 2014 survey, one third of the 18-40 age group is planning to emigrate in the near future, while the number of those who are already outside the country and are hoping to return is less than $10 \%$. These tendencies suggest serious problems not only for the economy of the country, but are foreseen to affect the birth rates and the overall aging of the population as well as the sustainibility of the social security system.

As the negative effects of emigration are becoming more and more visible in the country, the reclaiming of citizens living abroad is gaining primary importance in the Hungarian government's agenda. In 2013, in an attempt to enhance return migration, the State Secretariat for National Policy called the Körösi Csoma Sándor Programme to life. Describing the aim of the programme as the strengthening of the national identity in the Hungarian diasporas around the world through the dissemination of knowledge, educational activities and the organisation of community in order to consolidate the bonds between the home country and its population living abroad, the programme recruits Hungarian people who do not only possess patriotic values, but also excel at one or several traditional forms of art to travel to a diaspora assigned to them and act as facilitators of the above processes. On the website of the government, the goals of the programme are summarised in the following words: "Hungary is not willing to give up on its population living abroad and our hope is that the assimilation processes that are taking place in the host countries are stoppable or even reversible", which reflects the government's strategy of increasing transnationalism while contravening with participants' integration processes and illustrates the objectives the facilitators have to achieve in their respective project locations.

In order to ensure that the identity changes evoked by the programme are followed by an actual return, in 2016, the Ministry of Human Resources established the 'Gyere Haza Fiatal' (Come Back Home Young Person) programme, through which successful applicants could not only gain financial support for their repatriation, but according to the contract, would also be ensured a job that matches their qualifications back in Hungary. Although the trial period of the project has come to an end and the continuation of the 
programme has not been confirmed, as a subproject, the Gyere Haza Vállalkozni, Fiatal (Come Back Home to Start a Business Young Person) is already operating, offering grants to young people to return home and start a business there. Moreover, the services of the Gyere Haza Karrier Pontok (Come Back Home Career Points) are available free of charge to those looking for legal, psychological and job seeking assistance to help their repatriation.

Although Hungary saw a huge wave of people leaving the country in 1956 as a result of the revolution, historically, Ireland was never amongst the main destinations of Hungarian emigration and the Hungarian diaspora in the country only began to become significant during the last decade. This means that the 910.000 Hungarians who currently reside in the country are almost exclusively first-generation immigrants, having lived in Ireland for only a few years on average. However, given the relatively good living standard, the easy access to work due to the EU regulations, the national language being English and the ease of gaining citizenship, Ireland is currently the 6th most popular European destination amongst Hungarians (Bodnár and Szabó, 2014). In fact, Ireland's 2011 census report mentions Hungarians as one of the top three nationalities whose number is significantly increasing in the country (Irish Census 2011 Reports, 2012). Moreover, with the Brexit of 2016 evoking doubts about the long-term functionality of planned migration to the United Kingdom, Ireland is emerging as the 'next best destination' amongst Hungarians and is therefore foreseen to gain even more importance in the coming years.

\section{Preliminary research}

In March 2016, I conducted a preliminary research by interviewing 15 Hungarian emigrants living in Ireland to map out some tendencies present in the diaspora that might help the construction of my research plan. The study focused on people's motivation to leave the country; the process and feelings attached to their emigration; their perceived degree of integration into the host country; the extent to which being Hungarian was important to them; as well as their perception of the home country and their plans for return. On average, by the time of the interview, the participants had been living in Ireland for two years and four months, with the time spent in the country by the individual participants ranging between a little more than three months and eight years. Despite the fact that the planned research only focuses on the Dublin area, the participants of the preliminary research lived all over the country. Even though certain tendencies were perceived to be connected to the location chosen - such as families moving to the countryside but individuals moving to the capital; manual workers moving the countryside but skilled professionals moving to Dublin -, this was not perceived to affect the usability of the results.

Amongst the key findings, the study underlined the necessity to look into the economic factors involved in the migrant experience. Apart from two participants who opted for living in Ireland to seek adventure and one who came to the country to get married, the overwhelming majority of the respondents made their decision to emigrate because of circumstances emerging as a result of the economic crisis and described the emigration as not having been motivated by their wish, but by pure necessity. In fact, it was not a unique phenomenon amongst them to experience severe economic hardships, from 
which they were not able to recover in the country. Overall, the process of migration was largely interpreted as their expulsion by the home country, whereby many of them evaluated Hungary as having failed to cater for the needs of its citizens. This evoked an overall resentment in the participants towards the home country, which was made stronger by their repulsion of Hungarian politics and scepticism towards those directing the country. Moreover, the financial aspect was understood as being crucial in establishing a new life in the host country as well: when asking people why they chose Ireland specifically and what expectations they had of the country, they unanimously agreed that they were motivated by the perspective of financial stability and placed less emphasis on cultural and other considerations. Last, but not least, when enquiring into the perception of the notion of home, their decision on whether Ireland was interpreted as home or not was often linked to whether they had already achieved economic well-being in the country.

Secondly, when enquiring about the cultural identity of the participants, the majority of the interviewees claimed that the fact that they were Hungarian played little to no role in their lives. Especially amongst the older generation, the language difference was still highly affecting participants' perception of themselves as outsiders and this problem was identified as one that is hindering their integration. At the same time, the Hungarian language also proved to be a source of patriotic feelings and a basis for identity amongst roughly half of the participants. However, younger emigrants showed less attachment to their culture and identified no serious factors that stood in the way of their integration. Most commonly, the aspect of material culture that emigrants found crucial to preserve from their old lives was the Hungarian cuisine, which was emphasized by many as being core to their cultural identity.

There was a strong divide in people's wish to keep themselves informed about what is happening in Hungary, with some deeming it essential amongst their daily activities and others preferring to keep a distance from it. The same applied to people's participation in Hungarian communities in Ireland: while several people said they needed to keep in touch with their identity by meeting compatriots and some said they took part in Hungarian groups to be able to communicate in their mother tongue, others consciously refrained from engaging in such activities. In fact, while all of them maintained ties with family and friends whom they left behind, the majority of the participants claimed that when comparing themselves with other nationalities, they found Hungarians to be less likely to support each other, therefore, they did not show a strong desire to surround themselves with Hungarians in Ireland. Moreover, none of the 15 interviewees celebrated important Hungarian national days and showed little interest in participating in Hungarian programmes revolving around Hungarian arts or traditions.

Last, but not least, the research highlighted that without exception, all participants were satisfied with the conditions they found in Ireland and even if not all of them claimed to feel at home in the country or to have achieved the financial stability they came here for yet, they showed little to no willingness to return to Hungary. The reasons for this were manifold, however, the financial aspect was definitely less emphasized than expected based on the motivations to leave. In fact, people often told me that if the economy of Hungary was exactly the same like it is in Ireland that would still not be enough of a reason to 
prompt their return. Amongst the main reasons for not wanting to return were claims of feeling appreciated in the country, the tolerance and generally more liberal atmosphere in Ireland as well as the increased opportunities participants encountered in the country. Moreover, my interviewees were highly critical of their home country and agreed that many things had to change in Hungary from the political system to healthcare; from corruption to people's negativism for them to consider repatriating.

As illustrated by the research, the government's return campaign does not build on an existing demand from the side of the diaspora; in fact, in the light of the preliminary research, it seems more like a forced intervention to encourage people to return to their Hungarian reality. Mostly, participants evaluated their acculturation and integration as successful and they claimed to have gained most of the assets whose lack prompted their emigration. Moreover, they do not feel the need to keep in touch with the Hungarian culture and none of them have plans to return on the long run. Out of the 15 interviewees, around a quarter have already heard about the events of the Körösi Csoma Sándor programme or got invitations to them - however, only one of them has participated in them before and none of the others aspire to do so in the future. Moroever, none of them predict any significant change to be provoked by the Gyere Haza Fiatal programme and the large majority would never consider applying for it, which highlights the overall negativity towards the initiatives of the government.

\section{Proposed research}

During my one year research stay in Ireland, I would like to focus on the Hungarian government's return campaign and investigate how participation in the events organised within the frames of the Körösi Csoma Sándor programme affects first-generation Hungarian emigrants' motivation to return. Within this, I would like to dedicate special attention to the two pillars of the model proposed by Carling and Pettersen (2014), namely transnationalism and integration. First of all, I would like to understand whether participation in the events evokes any change in participants' Hungarian identity, their perception of the notion of home and of their ties to the motherland. Secondly, I would like to investigate how involvement in the programme results in changing perceptions of the self as being integrated into the host community. Last, but not least, while the study is primarily interested in questions of cultural identity, as highlighted by the preliminary research, the economic aspect of such processes cannot be left out of consideration and therefore, I would like to pay attention to how motivations to return are rooted in financial considerations as well.

The site of the proposed fieldwork is Dublin and the surrounding area, the territory assigned to be covered by one facilitator - therefore, the people in the focus of my study are the members of the Hungarian expatriate community residing in the Irish capital or its close vicinity. During my research, I will rely on methodological triangulation, with the major emphasis placed on participant observation and interviews and a minor role assigned to online participant observation. Although the project carried out by Boccagni (2011) on Ecuadorian migrants, which serves as an example for this study, relied on the analysis of the response of the diaspora community to the Ecuadorian government's 
campaign once it had already taken place, because of the nature of the Körösi Csoma Sándor programme, I decided to opt for the long-term observation of phenomena and focus on processes rather than end results. Therefore, my project will take place over a nine-month period between September 2016 and June 2017 and will be made up of three phases.

In the first phase encompassing a one-month period, I would like to gain access to the field not only by establishing contacts with members of the diaspora community, but by getting to know the new facilitator who is starting her assignment period in September and familiarizing myself with her project for the year. In this phase, I would like to gain access to the online forums Hungarians living in Dublin use to communicate with each other to look into the advice they give to people who are considering moving to Ireland and the stories they share with others about their emigration process, as well as their the difficulties and achievements.

From the second phase on, my attention will be devoted to people attending the events of the Körösi Csoma Sándor Programme and during this phase that is foreseen to last between October and March, I would like to participate in the events organised by the facilitator in Dublin. During this time, I will attend the biweekly 'How well do you know Hungary?' pub quiz and get together as well as one-off events organised around Hungarian national days, public holidays and different Hungarian themes. For instance, on 23rd October, for the 60th anniversary of the 1956 revolution, a large-scale commemoration highlighting questions of emigration and the loyalty of migrants to the home country is anticipated and on 15th March, the freedom of Hungary is to be celebrated through the staging of the events of the revolution. At these events, I would like to conduct participant observation and carry out short opportunistic interviews that focus on the question of return as well as participants' perception of the Körösi events and their goal.

During the second phase, I would like to find some regular attendees who are willing to be the subject of in-depth interviews. Ideally, I would like to visit them in their homes and ask them to explain to me how they live and how their new life differs from their old one in Hungary. During this activity, I will focus on their definition of financial well-being that was found to be of core importance to the emigration motivation by the preliminary research. I would also like to follow some of the participants on a few daily activities that reflects their everyday routine in the host country and see how much the home country is present in it. Moreover, I would like to benefit from the application of some experimental methods, for example the watching together of new campaign videos produced by the Hungarian government aimed at emigrants to get immediate feedback on participants' emotions evoked by them.

During the final, third phase of the project, I would like to rely on interviews to gain detailed feedback on people's experience of being addressed by the Körösi programme. I would like to find out what aspects of it they enjoyed, which of them evoked strong reactions in them and whether they perceive any change in their ties to and feelings towards the home country as a result. Moreover, if during the nine months, somebody decides to repatriate, I would like to conduct an interview with them to enquire about their motivations and how their decision was made. Moreover, if possible, I would like to ask them to 
keep a diary of the first few weeks after their return to find out if the reality of return matched their expectations.

In my analysis, I will rely on the approach highlighted above whereby the Hungarian emigrant community living in Ireland will be interpreted as a diaspora, whose identity is exposed to being formed by state-led transnationalism - however, my main emphasis will be on the individual's agency in the process. In the evaluation of the participants' identity formation and the success of the return campaign, I will apply Carling and Pettersen's (2014) 'integration-transnationalism matrix'. Within this, the integration dimension will serve to assess the changing ties with the host country and the extent to which the participation in the events uprooted participants' assimilation and their feelings of being at home in Ireland. The other axis will be constituted by an attention to the transnationalism evoked by the participation and how ties and affiliations emerge with the home country as a result. Although as highlighted above, the actual return might depend on various factors external to one's identity change, changes in integration and transnationality can be relied on as good measurements of the success of the programme. When analysing the motivation of those who did opt for return, however, I will pay attention to whether the process was primarily motivated by identity or economic factors to assess whether the highly financial nature of emigration can be offset purely by the enhancement of patriotic feelings.

\section{Conclusion}

All things considered, this paper aimed to provide an overview of the background material I found crucial to take into consideration when constructing my own research and it set out to describe the aspects in which they contributed to the choices made when drawing up the research plan. Hungary's campaign of attracting emigrants back to the home country to contribute to the economy was implemented in 2013 and therefore, has not attracted much scholarly attention yet. Although, as underlined throughout the present essay, the emigration situation in Hungary shows some unique aspects, the phenomenon fits into a broader literature of diaspora construction and state-led transnationalism, two notions that provide a backbone for my analysis. Moreover, a similar campaign initiated by the Ecuadorian government was found to share core aspects with the Hungarian case and the study conducted by Boccagni (2011) on the Italian Ecuadorian diaspora's response to the phenomenon serves as an example to be followed because of its treatment of identity issues in the context of return propaganda. As the framework of analysis to evaluate the success of the campaign, I identified Carling and Pettersen's (2014) 'integration-transnationalism matrix' as highly suitable as it looks at ties with both the host and the home country and assesses the prospect of return through these.

My preliminary research also aided the assessment of the tendencies present amongst members of the Hungarian diaspora community living in Ireland and drew attention to the predominant feeling of alienation from the home country that mostly resulted from the economic conditions that pushed for emigration. Members of the community did not show an interest in keeping in touch with their Hungarian roots and were mostly not interested in participating in 
Hungarian emigrant communities either; they mostly felt at home in Ireland; and the majority of them assessed their integration in the country to be successful, which underlines the controversial nature of the Körösi Csoma Sándor programme. Therefore, the question whether the programme can in fact have any substantial impact on Hungarian expatriates living in Ireland seems highly relevant. My proposed study aims to answer this question through the long-term analysis of the processes of identity formation taking place in participants through the mixed methods of participant observation at the events and interviews with regular attendees. The results of the study should bring us one step closer to understanding the way diasporas work and reveal important information about whether they can function largely independently or are in fact highly exposed to the manipulative power of the home country.

\section{References}

Adamson, Fiona B. (2008). "Constructing the Diaspora: Diaspora Identity Politics and Transnational Social Movements". In Lyons, Terrence and Mandaville, Peter (eds.) Politics from Afar: Transnational Diasporas and Networks. New York: Columbia University Press.

Anderson, Benedict (1983). Imagined Communities: Reflections on the Origins and Spread of Nationalism. London: Verso.

Blaskó, Zsuzsa et al. (2014). "Magyarok külföldön - Mennyien? Kik? Hol?" (Hungarians Abroad - How many? Who? Where?). In Kolosi, Tamás and Tóth, István György (eds.) Társadalmi Riport 2014. Budapest: Tárki. pp. 351-372.

Boccagni, Paolo (2011). "The Framing of Return from Above and Below in Ecuadorian Migration: a Project, a Myth, or a Political Device?" Global Networks 11(4), pp. 461-80. DOI: 10.1111/j.1471-0374.2011.00323.x.

(2011). "Reminiscences, Patriotism, Participation: Approaching External Voting in Ecuadorian Immigration to Italy". International Migration 49 (3), pp. 76 98. DOI: 10.1111/j.1468-2435.2011.00691.x.

Boccagni, Paolo and Lagomarsino, F. (2011). "Migration and the Global Crisis: New Prospects for Return? The Case of Ecuadorians in Europe". Bulletin of Latin American Research 30 (3), pp. 282-97. DOI: 10.1111/j.14709856.2010.00494.x.

Bodnár, Katalin and Szabó L. T. (2014). A kivándorlás hatása a hazai munkaeröpiacra (The Impact of Emigration on the Work Force in Hungary). Budapest: Magyar Nemzeti Bank.

Brubaker, Rogers (2005). “The 'Diaspora' Diaspora”. Ethnic and Racial Studies 28(1), pp. 1-19. DOI: 10.1080/0141987042000289997.

Butler, Kim D. (2001). "Defining Diaspora, Refining a Discourse". Diaspora 10 (2), pp. 189-219. DOI: 10.1353/dsp.2011.0014. 
Carling, Jorgen \& Erdal, M. B. (2014). "Return Migration and Transnationalism: How Are the Two Connected?" International Migration 52(6), pp. 2-12. DOI: 10.1111/imig.12180.

Carling, Jorgen \& Pettersen, S. V. (2014). "Return Migration Intentions in the Integration-Transnationalism Matrix". International Migration 52(6), pp. 13-30. DOI: 10.1111/imig.12161.

Conner, Walker (1972). "Nation-Building or Nation-Destroying". World Politics 24, pp. 319-55. DOI: 10.2307/2009753.

Gamlen, Alan (2008). "Why Engage Diasporas?" Working Paper 63, Centre on Migration, Policy and Society (COMPAS): University of Oxford.

Goldring, Luin (2002). "The Mexican State and Transmigrant Organisations: Negotiating the Boundaries or Membership and Participation". Latin American Research Review 37(3), pp. 55-99.

Guarnizo, Luis et al. (2003). "Assimilation and Transnationalism: Determinants of Transnational Political Action among Contemporary Migrants". American Journal of Sociology 108(6), pp. 1211-48. DOI: 10.1086/375195.

Irish Census 2011 Reports. (2012). Migration \& Diversity in Ireland - A Profile of Diversity in Ireland. Dublin: Central Statistics Office.

Itzigsohn, Jose (2000). "Immigration and the Boundaries of Citizenship: The Institutions of Immigrants' Political Transnationalism", International Migration Review 34(4), pp. 1126-54. DOI: 10.2307/2675977.

King, Russell (1999). "Generalizations from the History of Return Migration", in B. Gosh (ed.) Return Migration, Geneva: IOM.

Központi Statisztikai Hivatal (Central Statistics Office) (2014). Helyzetkép a magyarországi elvándorlásról (Overview of Hungarian Emigration). Budapest: SEEMIG.

Levitt, Peggy (2001). "Transnational Migration: Taking Stock and Future Decisions”. Global Networks 1(3), pp. 195-216.

Levitt, Peggy and de la Dehesa, R. (2003). "Transnational Migration and the Redefinition of the State: Variations and Explanations", Ethnic and Racial Studies 26(4), pp. 587-611. DOI: 10.1080/0141987032000087325.

Margheritis, Ana (2007). "State-led Transnationalism and Migration: Reaching out to the Argentine Community in Spain". Global Networks 7(1), pp. 87-106. DOI: 10.1111/j.1471-0374.2006.00158.x.

(2011). "Todos Somos Migrantes (We are All Migrants): The Paradoxes of Innovative State-led Transnationalism in Ecuador". International Political Sociology 5, pp. 198-217. DOI: 10.1111/j.1749-5687.2011.00129.x. 
Østergaard-Nielsen, Eva (ed.) (2003). International Migration and Sending Countries: Perceptions, Policies and Transnational Relations, Basingstoke: Palgrave Macmillan. DOI: 10.1057/9780230512429.

Portes, Alejandro (1999). "Conclusion: Towards a New World - The Origins and Effects of Transnational Activities". Ethnic and Racial Studies 22(2), pp. 463-77. DOI: 10.1080/014198799329567.

van Evera, Stephen (1994). "Hypotheses on Nationalism and War". International Security 18(4), pp. 5-39. DOI: 10.2307/2539176.

Weiner, Myron (1986). "Labor Migrations as Incipient Diasporas". In Sheffer, Gabriel. Moderns Diasporas in International Politics. New York: St Martin's Press, pp. 47-74. DOI: 10.1093/jrs/12.3.235. 